\title{
О.Н. Кондратьева
}

\section{ОСОБЕННОСТИ РАЗВЕРТЫВАНИЯ КОНЦЕПТУАЛЬНОЙ МЕТАФОРЫ В ЦИКЛЕ ПОЛИТИЧЕСКИХ АНЕКДОТОВ (НА МАТЕРИАЛЕ АНЕКДОТОВ О БАЛЛОТИРОВАНИИ КСЕНИИ СОБЧАК НА ПОСТ ПРЕЗИДЕНТА РОССИЙСКОЙ ФЕДЕРАЦИИ) ${ }^{1}$}

\begin{abstract}
Описаны особенности развертывания в анекдотах метафоры, репрезентирующей баллотирование в президенть Российской Федераџии Ксении Собчак. Установлено, что развертывание доминирующей метафоры в анекдотах способствует их восприятию как единого иелого, иикла. Выявлена доминирующая метафора (зооморфная), описаны структурирующие ее фреймы и слоты, установлены причины ее продуктивности, отмечена способность доминирующей метафоры притягивать метафоры из смежных сфер.

Ключевые слова: концептуальная метафора, развертыввание концептуальной метафоры, политический анекдот, президентские выборы-2018, Ксения Собчак.
\end{abstract}

Политическая лингвистика сосредоточена на изучении политической коммуникации и рассмотрении способов борьбы за власть в процессе воздействия на политическое сознание общества. В современной политической коммуникации отчетливо выделяются две ее разновидности - институализированная (осуществляемая субъектами профессиональной и общественной деятельности, т.е. политиками, политологами и журналистами) и неформальная (осуществляемая рядовыми гражданами) (см. подробнее, например, [1. С. 207; 2. С. 36-37] и др.). Неформальная политическая коммуникация отличается «от институализированной прежде всего тем, что она не поддается жесткому контролю, а также сложно предсказать результат ее влияния на общество» [1. С. 207]. К неформальной политической коммуникации относятся политические мифы, конструируемые обществом, политические анекдоты, политические карикатуры, политические сплетни и слухи.

Важным жанром политической коммуникации является анекдот, именно в анекдотах содержатся наиболее яркие, эмоциональные реакции на события, разворачивающиеся на политической арене, отражается отношение авторов и рассказчиков анекдотов к происходящему. Не случайно историки и политологи все чаще избирают анекдоты как источник для изуче-

\footnotetext{
${ }^{1}$ Исследование выполнено при финансовой поддержке РФФИ в рамках научного проекта № 19-012-00522 «Проблема легитимизации в политическом дискурсе: лингвоперсонологический аспект».
} 
ния политической ситуации и общественных настроений в определенные периоды существования нашей страны (см., например, работы В.В. Алексеева [3], Д.А. Будко [4], М.А. Мельниченко [5], О.В. Фроловой [6] и др.), подобный выбор определяется тем, что осмыслению в форме анекдотов подвергаются преимущественно политические события, вызвавшие наиболее сильный общественный резонанс. Соответственно, анализ событий, получивших интерпретацию в виде анекдотов, выявление аспектов ситуации, подвергшихся юмористической рефлексии, позволяют установить наиболее острые точки жизни общества и выявить их оценку обществом.

Лингвистические исследования политических анекдотов - одно из интенсивно развивающихся направлений политической лингвистики (В.И. Карасик [7], М.Р. Желтухина [8], И. В. Култышева [9], Е. Я. Шмелева, А.Д. Шмелев [10] и др.). Объектом изучения становятся интертекстуальные связи в анекдотах, позволяющие вписать их в определенный политический контекст, речевые маски персонажей-политиков, роль анекдотов в информационной войне и др. Недостаточно изученными, на наш взгляд, остаются особенности функционирования в политических анекдотах метафор, хотя метафоричность является важной особенностью текстов данного жанра. Например, Н.В. Нагуш называет метафоричность одной из двух главных лингвистических характеристик жанра и указывает на ее смехопродуцирующую функцию [11. С. 4].

Современные подходы в изучении метафоры (когнитивный и лингвокультурологический) позволяют утверждать, что метафора в анекдотах выполняет не только традиционно приписываемую ей смехопродуцирующую функцию (создает комический эффект), но и ряд других функций, в частности прагматическую (эффективно воздействует на адресата и формирует необходимое эмоциональное отношение к происходящему), эвфеместическую (передает в анекдоте в завуалированном виде информацию, которую автор не счел возможным выразить в открытой форме в иных жанрах), прогностическую (моделирует вероятностные модели развития той или иной политической ситуации). Основной же функцией метафоры, реализуемой том числе и в жанре анекдота, является функция когнитивная. Путем установления аналогий между сферой-источником и сферой-мишенью моделируется определенный фрагмент мира, т.е. осуществляется процесс познания (см. работы Дж. Лакоффа и М. Джонсона [12], А.Н. Баранова [13], И.М. Кобозевой [14], 3.И. Резановой [15], А.П. Чудинова [16] и др.).

С нашей точки зрения, в анекдотах концептуальная метафора выполняет еще одну важную функцию - циклоообразующую, обусловленную способностью метафоры к развертыванию в тексте или группе текстов. По наблюдениям А.П. Чудинова, «способность к развертыванию в тексте важнейшее свойство концептуальной метафоры», обеспечивающее связь его частей, обеспечивающее целостность восприятия [2. С. 150]. Особенности развертывания метафоры в разных дискурсах становились объектом исследования в работах И.М. Кобозевой [14], Е.В. Колотниной и Т.А. Вагановой [17], А.П. Чудинова [2] и др. 
Развертывание метафоры в анекдотах имеет свою специфику: использование одной доминантной метафоры и ее развертывание происходит не только в пределах одного текста, но и в группе текстов (анекдотов), объединенных общей тематикой, что способствует их восприятию как определенного единства, как некоего гипертекста, неделимого целого, цикла. Однако до сих пор метафора, репрезентирующая в анекдоте конкретное политическое событие, и особенности ее развертывания в цикле анекдотов, посвященных данному политическому событию, не становились объектом специального исследования.

Предлагаемая статья посвящена описанию особенностей развертывания в анекдотах метафорической модели, репрезентирующей значимое для современной российской политической действительности событие - выдвижение в кандидаты в президенты Российской Федерации кандидатаженщины, а именно - Ксении Собчак.

Материалом исследования послужили анекдоты, представленные на сайте «Анекдоты из России» [18] за период с 14 октября 2017 до 1 января 2018 г., посвященные предстоящим президентским выборам 2018 г. в России. В настоящее время благодаря Интернету и социальным сетям можно проследить, насколько оперативно общество реагирует на те или иные политические события. По наблюдениям Е.Я. Шмелевой и А.Д. Шмелева, «первые анекдоты - отклики на какие-то события... появляются через дватри часа после того, как об этих событиях сообщают средства массовой информации» [19. С. 185]. Затем в течение некоторого времени число анекдотов достигает пика и постепенно идет на спад.

О своем намерении участвовать в президентских выборах Ксения Собчак заявила 18 октября 2017 г., первые анекдоты на данную тему появились на сайте «Анекдоты из России» на следующий день, затем ежедневно на сайте появлялось по 10-30 анекдотов, всего за период с 19 по 29 октября на сайте было зафиксировано 136 анекдотов, после чего их количество резко пошло на спад, периодически появлялось по 1-2 анекдота в неделю, т.е. событие себя исчерпало и поток креативных идей иссяк.

В анекдотах, представленных на сайте, активно подвергались комизации различные черты внешности и характера Ксении Собчак, факты ее биографии (папа губернатор, образование, гламурный образ жизни, активное посещение светских мероприятий, участие в качестве ведущей в проекте ДОМ-2 и др.), подобным образом создавался негативный образ кандидата в президенты, высмеивались претензии Ксении на серьезные политические поступки ${ }^{1}$.

В большинстве анекдотов активно использовались такие средства создания комического, как каламбур, гипербола, нарушение лексической сочетаемости, отсылка к прецедентным текстам и др. В ряде анекдотов авто-

\footnotetext{
${ }^{1}$ Факт анализа приведенных в статье политических анекдотов не свидетельствует о том, что автор публикации или редакционная коллегия в какой-либо степени солидарны с позицией создателей данных текстов.
} 
ры использовали метафоры, большая часть которых имела своими источниками понятийные сферы «шоу-бизнес», «театр» и «кино», что напрямую коррелирует с основными сферами деятельности Ксении Собчак. Доминирующими же в цикле анекдотов об участии Ксении Собчак в президентских выборах стали зооморфные метафоры (львица, лошадь, собака), представленные в 79 анекдотах из 136, что составляет 58\%. Ядерную группу среди зооморфных метафор образуют метафоры лошади, представленные в 72 анекдотах, что составляет 52,9\% от общего объема. «Лошадиная» метафора, характеризующая Ксению Собчак, появилась задолго до начала президентской гонки 2018 г., однако в изучаемый период данная метафора значительно увеличила свою частотность, стала более структурированной, приобрела новые дополнительные смыслы, получила возможность развертывания в пределах как одного анекдота, так и всего цикла, т.е. стала своеобразной скрепой, объединившей цикл анекдотов обозначенной тематики.

Продуктивность лошадиной метафоры для репрезентации участия Ксении Собчак в предвыборной гонке определяется, на наш взгляд, рядом факторов.

Во-первых, в массовой лингвокультуре уже стало устоявшимся сравнение Ксении Собчак с лошадью. Оно регулярно реализуется в многочисленных пародиях, юмористических шоу, интернет-мемах, анекдотах, да и сама Ксения со свойственной ей самоиронией периодически шутила на данную тему. Неоднократно было отмечено, что «современные русские обращаются к образу лошади при характеристике девушки или молодой женщины, крупного телосложения, крепкой и сильной физически; человека, во внешности которого обнаруживается сходство с чертами лошади, человека с крупными зубами (отсюда лошадиная улыбка) [20. С. 41]. Именно на этих особенностях внешности К. Собчак постоянно акцентируется внимание в Интернете, например, популярными стали визуальные ряды, на которых дается изображение Ксении и лошади:
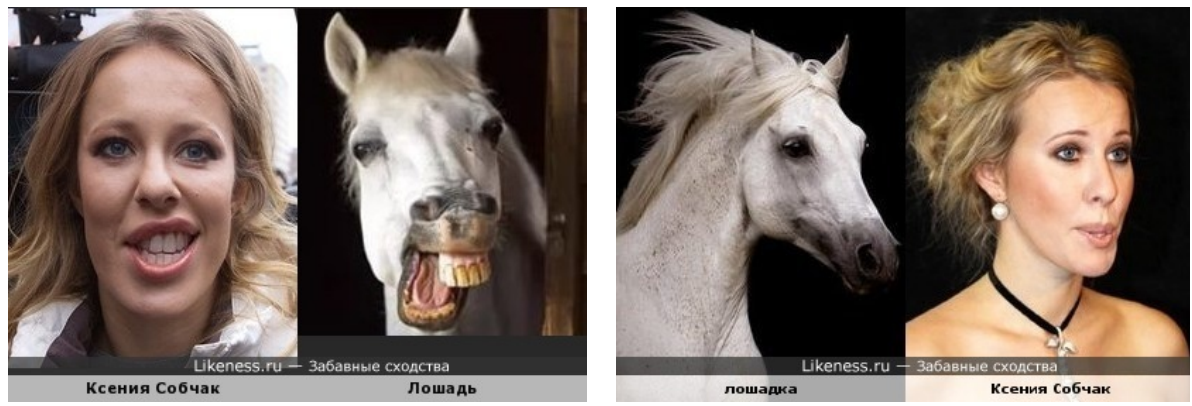

Многочисленные анекдоты, появившиеся в начале телевизионной карьеры Ксении Собчак, также активно эксплуатировали данную тему: 1) Урок в начальной школе. Учительница: - Дети, возьмите в руки карандаши и листок бумаги. Сегодня мы будем учиться рисовать лошадку. А Ксюшенька Собчак все это время постарается сидеть тихо-тихо и не ше- 
велиться; 2) Ксюша Собчак жалуется поручику Ржевскому на то, что недруги сравнивают ее лицо с лошадиной мордой. «Это наглая ложь!» возмутился поручик. - «Ничуточки не похоже. Лошадь - животное благородное и морда у нее красивая, я бы даже сказал, одухотворенная»; 3) Тут многие пицут о Ксении Собчак, типа, чем она отличается от лошади. Я думаю, зря это все. Ничем таким от нее она не отличается.

Кроме того, сравнениям Ксении Собчак с лошадью способствует и ее свободолюбивый, независимый, отчасти даже норовистый характер, зачастую непредсказуемое и раскованное поведение, громкий заливистый смех (ср. устойчивое выражение ржет как лошадь).

Во-вторых, образ коня является значимым для русской лингвокультуры, он представлен в мифологии, фольклоре, литературных произведениях. Лексемы конь / лошадь входят в значительное количество текстов, которые стали прецедентными.

В-третьих, связанные с лошадями образы скачек, гонок, ипподрома, тотализатора и цирка традиционно использовались для метафорического обозначения предвыборных гонок и избирательных кампаний разного уровня (подробнее см.: [16. С. 113-131]).

Сочетание указанных факторов определило продуктивность метафор «Кандидат в президенты (Ксения Собчак) - лошадь», «Предвыборная кампания - скачки» в российских анекдотах. Данная метафора, заложенная уже в первых анекдотах, системно и структурированно развертывается в большинстве последующих анекдотов.

В процессе развертывания исходной метафорической модели в анекдотах используются разнообразные приемы. Это может быть собственно метафоризация, деметафоризация (использование метафоры в буквальном значении), реметафоризация (оживление стертой метафоры). Частотны также случаи, когда «лошадиные» лексемы используются в анекдоте в их прямом значении, но подтекст или окружающий контекст позволяет адресату понять, что речь идет о президентских выборах, что также в итоге работает на исходную лошадиную метафору, объединяющую изучаемый цикл анекдотов.

В предлагаемой работе используется максимально широкое понимание метафоры, обусловленное убеждением когнитологов в том, что понятийное сближение является более важным фактором, чем уровневые или структурные различия, соответственно, язык при таком подходе предстает как единый континуум символьных единиц. При таком подходе в объем метафоры включаются любые лексические и морфологические дериваты, созданные с использованием общих смысловых механизмов аналогического уподобления [13. С. 83-93; 15. С. 284; 16. С. 37; 21. С. 314]. Основным при таком рассмотрении образных средств является не их языковая форма, а лежащие в их основе аналоговые механизмы.

Развертывание лошадиной метафоры в цикле анекдотов, посвященных предстоящим выборам президента Российской Федерации и сфокусированных на кандидатуре Ксении Собчак, осуществляется в рамках пяти фреймов, каждый из которых структурируется некоторым набором слотов. 
1. Фрейм «Лошади, их виды и объединения». В рамках данного фрейма для метафорической характеристики Ксении Собчак как кандидата в президенты используются прямые номинации данного животного, косвенные отсылки к образу лошади, лексемы, называющие конкретных представителей данного вида и сказочных / фольклорных персонажей, а также наименования объединения лошадей (табун, стадо).

1.1. Слот «Лошадь». В данном слоте представлены разнообразные по способам лексического выражения, а также по способам формирования комического эффекта метафоры, объединенные общим направлением метафорического переноса «Лошадь» $\rightarrow$ «Ксения Собчак».

Первоначально подобные метафоры эксплуатируют преимущественно представления о внешнем сходстве лошади и нового кандидата в президенты, при этом данное сходство представляется в анекдотах опосредованно, через отсылку к теме ипподрома, подразумевается, что говорящий не сразу различил Ксению Собчак среди находившихся там лошадей: $\boldsymbol{H a}$ ипподроме была замечена Ксения Собчак. Не сразу была замечена. Авторы анекдотов при сравнении Ксении Собчак с лошадью обыгрывают и ее репутацию светской львицы, тем самым выражают недоумение от смены Ксенией жизненного амплуа: Ну все, приехали! Я совсем запутался! Новый кандидат. Лошадь?!!! Пипе-е-ец! Куда львицу-то подевали?

Затем образ лошади становится источником многочисленных ассоциаций, связанных с данными животными, и порождает разноплановые вариации на заданную тему. На сайте анекдотов даже появляется «конструктор» анекдотов про Ксению Собчак:

Julia
Фju_iss
шутокеологизмы-конструктор для сборки
1) темная лошадка
2) ход конем
3) поставить не на ту лошадь
4) бред сивой кобылы
20:26- 18 окт. 2017 г.

В результате в политических анекдотах о выборах президента лошадь начинает восприниматься как животное, являющееся символом Ксении Собчак, в связи с этим даже обыгрывается тема смены герба Российской Федерации в случае гипотетической победы Собчак на выборах, новым геральдическим знаком в этом случае становится символ победившего кандидата - лошадь: Давайте, чисто гипотетически, представим, что будет, если Ксюша Собчак и правда станет президентом РФ... На гербе Российской Федерачии двуглавый орёл будет заменен на лошадь.

Метафорическое значение при характеристике нового кандидата в президенты в анекдотах регулярно приобретают лексемы конь, лошадь, кобы- 
ла и их производные: 1) Сльшиали, Собчак баллотируется в президентыл. Это утка? - Нет, это лошадь!; 2) В чем разница между К. Собчак и лошадью Калигулье? - Ломадь Калигуль сама стала сенатором, а лошадка Ксюша только дочка сенатора; 3) А что, отец, кандидаты в президенты у вас есть? - Кому и кобыла кандидат; 4) Царей в России много было, но чтобы правила кобыла... Показательно, что постепенно в анекдотах подобного плана перестает упоминаться имя Ксении, подразумевается, что читатели итак прекрасно понимают, о ком идет речь.

Развитие лошадиной темы при характеристике кандидата в президенты достигается также за счет языковой игры, например видоизменения написания слова кандидат: На президентских выборах появилась новая коньдидатура и использования модифицированных прецедентных текстов, например фрагмента из стихотворения М.Ю. Лермонтова «Бородино»: Все смешалось: кони, люди. Выборы 2018.

Большая часть метафор, входящих в данный слот, эксплицирует признаки неожиданного появления Ксении Собчак среди кандидатов в президенты, отражает удивление непрофессиональных участников политической коммуникации изменившимися жизненными установками светской львицы, акцентирует внимание на включении в список кандидатов случайных, с их точки зрения, персонажей.

1.2. Слот «Bиды и породы лошадей». Для характеристики кандидата в президенты используются также лексемы, обозначающие конкретные виды и породы лошадей (лошадь Пржевальского, рысак и др.), а также номинации лошадей, являющихся персонажами мифов и сказок (троянский конь, конек-горбунок, Сивка-бурка): 1) Владимир Владимирович посмотрел предвыборный список и приказал вызвать Пескова. - Что за сброд? Вы бы ещце лошадь Пржевальского сюда включили! - сказал он сурово. Кто же знал, что Песков воспримет его слова так буквально;2) «На гербе заменить двуглавого орла на тройку рысаков». Да, да! Это первый указ всенародно избранной главы государства; 3) Россия - страна безграничных возможностей: конек-горбунок, Сивка-бурка, лошадь-Президент... Образы лошадей из народных сказок подчеркивают нереальность выдвинутой кандидатуры. То есть авторы анекдотов подобным образом стремятся показать, что данная кандидатура нужна исключительно для создания массовки на выборах и только верящие в сказки наивные люди способны воспринимать ее всерьез.

Неожиданность появления нового кандидата в президенты, его потенциальная опасность, непредсказуемость репрезентируются в анекдотах через установление аналогий с троянским конем и темной лошадкой: 1) Ксения Собчак - троянский конь российской демократии; 2) Сльпиали, что Собчак перекрасилась в брюнетку? - Видимо, она решила, что на выборах может победить только темная лошадка!

1.3. Слот «Объединения лошадей». В рамках данного слота в метафорическом значении в анекдотах о выборах президента для обозначения избирателей, не имеющих собственного мнения и предрасположенных к 
совершению неверного выбора, используют лексемы табун, стадо. Избрав Ксению Собчак президентом, население из стада превратится в табун.

2. Фрейм «Особенности строения и поведения лошадей». Данный фрейм создает яркую характеристику Ксении Собчак за счет актуализации особенностей внешности лошадей и особенностей их поведения, проецируемых на нового кандидата в президенты.

2.1. Слот «Особенности строения лошадей». Метафорическое значение приобретают лексемы, обозначающие различные части тела лошади: круп, копьта, корпус, грива: 1) Из интервью одного из кандидатов на пост президента России. - Ксения, как Вы относитесь к тому, что Навальный планирует участвовать в выборах? - Только через мой круп! (во фразе обыгрывается выражение «только через мой труп». - O.К.); 2) Демократическая Россия, преемнища страшного тоталитарного СССР, за 26 лет прошла огромный путь - от страны, где каждая кухарка могла управлять государством, до страны, где любая лошадь может двинуть копыта в президенты; 3) В предвыборной гонке Ксения Собчак пока на целый корпус обходит остальных кандидатов.

2.2. Слот «Особенности поведения лошадей». К особенностям поведения лошадей, акцентируемым в русской лингвокультуре, относятся их способность издавать характерные звуки (ржание), быстрота перемещения, способность к неожиданным движениям (взбрыкивать, лягаться).

Выступления Ксении Собчак уподобляются в анекдотах конскому ржанию, для этого используется как соответствующий глагол, так и звукоподражание (и-го-го): 1) Предвыборнылй слоган кандидатки в президентьл «И-го-го!»; 2) В день президентских выборов и в последний день передними будет запрещено изображать ржание.

Переносное значение лексемы ржать - 'чрезмерно громко, несдержанно смеяться' [22], соответственно, подобные звуковые характеристики применительно к кандидату на высший пост в стране демонстрируют несерьезность намерений Ксении, формируют скептическое отношение к ее программным заявлениям: 1) - Ксения, вот Bы зачем баллотируетесь на пост президента? - Да так, чисто поржать! 2) На стадион врывается Ксения Собчак, обходит первого, второго и с диким ржсанием уносится в противоположную от Кремля сторону!

Глагол брыкаться и производные от него обозначают 'резкие, неожиданные движения ногами', используются для характеристики животных, преимущественно - лошадей, глагол отбрыкаться развивает переносное значение 'отказаться, отделаться от чего-либо', однако используя его применительно к Ксении Собчак, создатели анекдотов ориентируют читателей на его буквальное прочтение: Говорят, Владимир Владимирович сделал Ксении Анатольевне такое предложение, от которого она не смогла отбрыкаться.

3. Фрейм «Предметы и продукты, связанные с лошадьми». Уход за лошадьми, их подготовка к работе предполагают применение специализи- 
рованных предметов и средств, наименования которых используются в анекдотах в переносном значении.

3.1. Слот «Упряжь». Для участия в президентской гонке кандидатлошадка нуждается в соответствующей экипировке, в частности в упряжи / сбруе, т.е. в совокупности 'предметов и приспособлений для запряжки лошадей' [22]. В анекдотах упоминаются такие элементы лошадиной упряжи, как седло, удила, узда: - А вот это все обязательно? Седло, жокей? - Ксения Анатольевна, но Вы же сами выразили желание участвовать в президентской гонке.

Приспособление для предохранения копыт лошади - подкова - также является обязательным для успешного участия в гонке. Кроме того, создатели анекдотов, характеризуя подготовленность Ксении Собчак к участию в крупном политическом событии, активно используют лексему подкованная ('подготовленная, обладающая запасом нужных сведений и знаний'), обыгрывая ее первое значение ('с прибитыми к копытам подковами'), что также создает комический эффект и формирует впечатление, прямо противоположное заявленному: Конечно же, Собчак победит. Она так подкована во всех этих политических вопросах! Подобным образом названная метафора разворачивается и в креолизованных текстах:

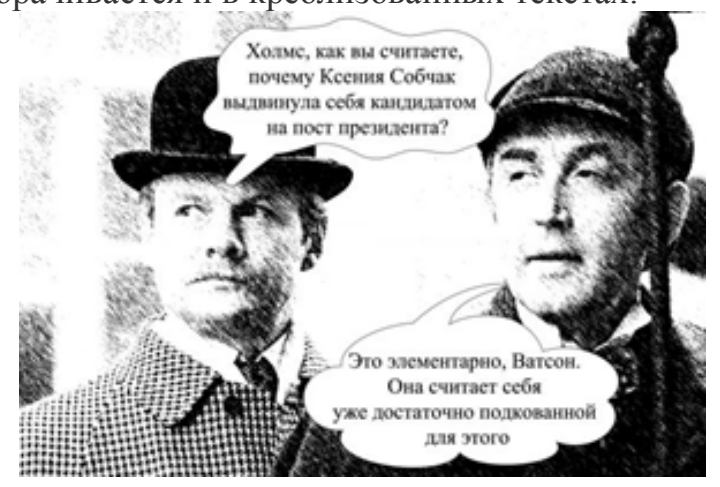

В представленном выше изображении акцентируется внимание адресатов на том, что «подкованной», т.е. подготовленной к выборам, считает себя сама Ксения, для обладающих же мощным интеллектом персон (не случайно эти слова вкладываются в уста интеллектуального гения Шерлока Холмса) это, мягко говоря, далеко не очевидно.

Символ подковы обыгрывается и при изобретении названия предстоящей президентской гонки, при этом название «Подкова» создатели анекдотов связывают не столько с восприятием предвыборной кампании как скачек, сколько с участием в этом событии Ксении Собчак: После того как Ксения Собчак решила баллотироваться в главнокомандующего России, президентскую гонку было решено переименовать в «Подкова-2018».

3.2. Слот «Продукты, связанные с лошадьми». Один из наиболее известных продуктов, связанных с лошадьми, - это колбаса из конины, созданная тюркскими народами и превратившаяся в деликатес для любите- 
лей. Данный образ создатели анекдотов используют для демонстрации альтернативы честолюбивых устремлений нового кандидата в президенты: 1) Не каждая лошадь может стать президентом. Но многие могут стать колбасой; 2) K выборам президента в России 2018 в Башкирии наладят запуск линии по изготовлению новой колбасы - «Президентская» из конинь.

Популярным брендом, активно продвигаемым массмедиа с участием звезд шоу-бизнеса, является косметический бренд «Лошадиная сила». Развитие образа кандидата-лошади происходит в анекдотах при сопряжении наименования данного бренда с избирательной кампанией Ксении Собчак: «Ломадиная сила»-офиџиальный спонсор кандидата в президенты Ксении Собчак.

4. Фрейм «Специалисты, работающие с лошадьми». При характеристике предвыборной гонки в анекдотах активно используются наименования лиц, задействованных в уходе за лошадьми (конюх) или участвующих в мероприятиях с участием лошадей (гонках, представлениях) - конюх, наездник, жокей: 1) Идет конюх Иван, а рядом с ним кобыла. Спрашивают сельчане: - Куда ведешь? - На убой. - А мы подумали, что к президенту на беседу о предстоящих выборах; 2) А вот это все обязательно? Седло, жокей? - Ксения Анатольевна, но Вы же сами выразили желание участвовать в президентской гонке; 3) Пока все внимание на выборах отвлечено на лошадь, никто не заметит, что некоторые наездники давно из седла валятся.

Примыкает к названной группе и лексема конокрад, при этом комический эффект создается за счет ее соединения с новомодной лексемой хакеpbl: Срочно требуются хакеры-конокрады для вмешательства в президентскую кампанию Ксении Собчак. В данном случае воровство информации из штаба кандидата сопоставляется с кражей лошадей.

5. Фрейм «Сферы, в которых задействованы лошади». С древнейших времен лошади использовались в разных сферах человеческой деятельности, это сельское хозяйство, транспорт, спорт, азартные игры и зрелища. В анекдотах об участии Ксении Собчак в выборах регулярно упоминаются такие объекты и проходящие в них мероприятия, как ипподром / стадион / скачки / и цирк / представление.

5.1. Слот «Ипподром». Ипподром представляет собой комплекс сооружений для испытаний лошадей и соревнований по конному спорту, а также учреждение, их организующее. В метафорическом значении лексема ипподром используется для характеристики выборов и участия в них Ксении Собчак, а также для ее дальнейшей творческой деятельности: 1) Предвыборная гонка превратилась в ипподром; 2) На ипподроме зрители скандировали: Собчак-чемпион! 3) Выдающиеся певцы, артисты, проповедники собирают полнье зальл и стадионы. Ксения, вероятно, будет собирать полные ипподромы.

Происходящие на ипподроме лошадиные бега могут быть двух видов: это может быть исключительно спортивное соревнование, гонка, а может 
быть и азартное состязание, предполагающее наличие тотализатора и ставок на победителя.

Репрезентация предвыборной кампании как спортивного состязания реализуется за счет метафорического использования лексем стадион, скачки, скакать, гонка и др.: 1) Итак, мы продолжаем репортаж со скачек заранее проигравших кандидатов. Пока все спокойно: на границе России уже третий год топчется Ходорковский, навальный скучно жует в автозаке щелки от «Кировлеса». И тут вдруг на стадион врывается Ксения Собчак... 2) - Скачи во весь опор, ведь это президентская гонка, - давал наставления президент Ксении; 3) В предвыборной гонке с огромным отрывом побеждает лошадь Путина.

Интерпретация предвыборной кампании как азартного мероприятия достигается за счет метафорического использования лексем и словосочетаний тотализатор, ставка, поставить на лошадь и др.: 1) При участии Собчак это уже будут не выборы, это будет тотализатор; 2) Если Собчак не наберет голосов, то можно ли будет сказать, что поставили не на ту лошадь? 3) Спонсор - кандидату в президенты: - Я поставил на тебя все свои деньги! Почему в предвыборной гонке ты не пришла к финишу первой? - Ну не шмогла я, не шмогла.

Оба типа метафор объединены общими признаками - соревнование, стремление победить, достичь финиша первым. Но если с помощью спортивной метафоры выборы предстают как честное состязание, с помощью азартноигровой - как соревнование, в котором могут иметь место махинации, нарушения правил, подкуп участников для достижения цели, т.е. эксплицируется стремление кандидатов в президенты победить любой ценой, указывается на заказной характер мероприятия, проплаченное участие некоторых кандидатов (в данном случае - Собчак как подставного кандидата) в выборах.

5.2. Слот «Цирк». Цирковая метафора позволяет представить политические события как заведомо постановочные, оценивает их как «нечто абсурдное, где отсутствует логика сюжета, а действующие лица подобны клоунам, иллюзионистам, фокусникам, канатоходцам» [23]. При характеристике Ксении Собчак цирковая метафора зачастую соседствует с метафорой шоу, что определяется ее интегрированностью в мир шоу-бизнеса. Соответственно, баллотирование Ксении Собчак в президенты расценивается создателями анекдотов как очередное шоу и цирк: Ксения Собчак возврашиается в шоу «Цирк со звездами».

Активное использование в анекдотах на предвыборные темы устойчивого выражения циик с конями, определяемого как 'смешная, абсурдная, крайне странная ситуация' [24], не только отсылает адресатов к образу Ксении Собчак, развивая сформировавшуюся задолго до начала предвыборной гонки метафору, но и создает образ выборов как достаточно нелепого и даже абсурдного представления: 1) Раньше выборы в России были просто цирком. Теперь стали цирком с конями; 2) Президентские выборы в России раньше пьтались оживить массовкой из кандидатов. Теперь к ней добавились женский кордебалет и цирк с конями. 
5.3. Слот «Шахматы». Интеллектуальная игра, зародившаяся в глубокой древности, предполагает использование фигур, одной из которых является шахматный конь. Данная фигура - одна из ключевых в шахматной партии, ее особая роль отразилась и в появлении фразеологизма сделать ход конем, т.е. 'совершить неожиданный, хитрый ход, обходной маневр в каком-либо противостоянии'. Именно так расценивается появление кандидата-женщины, что уже достаточно необычно для российской политики, обладающей к тому же достаточно специфической репутацией.

Комический эффект в анекдотах достигается за счет замены лексемы конь на лексему лошадь, отражающую гендерную характеристику нового кандидата в президенты: 1) Путин сделал ход конем! Ой, извините, лошадью....; 2) Российские политологи выпустили новое пособие по ведению предвыборной агитаиии. Называется «ХОД ЛОШАДЬЮ».

Усиление комического эффекта происходит за счет многочисленных отсылок к прецедентному тексту, к ставшей крылатой фразе из всенародно любимого фильма «Джентльмены удачи»: 1) Путин пересмотрел фильм «Джентльмены удачи» и как политический гроссмейстер прислушался $\kappa$ совету «Лочадью ходи, век воли не видать!»; 2) Лошадью, лошадью ходи, - подсказали Путину; 3) Лошадью ходи! Век воли не видать! Президент России прислушался к мнению советников.

Показательно, что с помощью использования в анекдотах шахматной метафоры президентские выборы представляются как тщательно продуманная комбинация, шахматная партия, а Владимиру Путину отводится роль гроссмейстера, имеющего четкую стратегию достижения поставленной цели и умело переставляющего фигуры на шахматной доске.

Обращает на себя внимание отсутствие в анекдотах метафор, связанных с участием лошадей в сельскохозяйственных работах или с их использованием как тягловой силы, транспортного средства, т.е. с тяжелым трудом лошадей, столь характерным для русской лингвокультуры (ср. устойчивые выражения «рабочая лошадь», «ломовая лошадь», «тягловая лошадь»). На наш взгляд, это объясняется тем, что в анекдотах представлен стереотипный образ Ксении Собчак, существующей исключительно в мире гламура и шоу-бизнеса.

Создатели анекдотов игнорируют наличие у Ксении Собчак хорошего образования (МГИМО, магистратура с отличием), владение тремя иностранными языками и достаточно плотный рабочий график: большую часть своей карьеры она трудилась одновременно в достаточно разноплановых проектах: выступала в роли теле- и радиоведущей, вела музыкальные премии и корпоративы, озвучивала фильмы, снималась в рекламных роликах и фильмах, записывала песни, вела колонки в журналах и писала книги, участвовала в движении гражданской оппозиции.

Тем не менее данные виды деятельности традиционно не воспринимаются как серьезная работа и в сознании большинства россиян Ксения Собчак предстает исключительно как праздная светская львица, представительница золотой молодежи, обязанная благосостоянием не своему труду, 
а усилиям родителей, «главный поп-символ ушедших нулевых». Это и определяет использование в анекдотах при характеристике Ксении сравнений исключительно с породистыми лошадями, участвующими в цирковых шоу или бегах, т.е. существующих в атмосфере веселья, драйва и роскоши. Соответственно, подобные образы не коррелируют с серьезной работой, которую россияне ждут от президента своей страны, и подобное развертывание исходной метафоры создает негативный образ Ксении Собчак как кандидата на данный пост.

Проведенное исследование позволяет сделать следующие выводы:

1. Анекдоты, посвященные выдвижению Ксенией Собчак своей кандидатуры для участия в президентских выборах 2018 г., представляют собой единый цикл, который объединен доминирующей метафорой - «Кандидат в президенты (Ксения Собчак) - это лошадь (темная лошадка или троянский конь)». В процессе развертывания исходной метафоры в цикле анекдотов возникают и получают развитие смежные метафоры: «выборы президента - это скачки / ипподром / цирк», «президент - организатор скачек / тотализатора», «альтернативные кандидаты - наездники», «избиратели - табун / стадо».

2. Исходная зооморфная метафора в процессе развертывания начинает активно притягивать метафоры из смежных сфер, в которых в той или иной форме присутствуют лошади. В анекдотах при развертывании доминирующей метафоры для создания единого образа Ксении Собчак используются наименования лиц, осуществляющих уход за лошадьми и взаимодействующих с ними (конюх, наездник, жокей, конокрад и др.), наименования элементов лошадиной экипировки (седло, узда, упряжь), наименования мест, в которых трудятся лошади (цирк, стадион, ипподром).

3. Метафора лошади, используемая для характеристики Ксении Собчак, сформировалась задолго до начала президентской гонки-2018, однако в изучаемый период она резко увеличила частотность, стала более структурированной, нарастила дополнительные смыслы. Если ранее мишенью метафорической экспансии являлись исключительно внешность и поведение Ксении, то в изучаемый период акцент делается на неожиданности появления ее кандидатуры в списке претендентов на должность президента, заказном характере выдвижения данной кандидатуры, несерьезности ее намерений, негативных последствиях, которые будут иметь место в случае ее маловероятной победы. То есть на ее несоответствии, с точки зрения создателей анекдотов, посту, на который она претендует, нелогичности и абсурдности происходящего. Также следует отметить, что анекдоты, предшествующие выдвижению Ксении Собчак в президенты, отличались легкой иронией, в изучаемый период в них преобладает сарказм, происходит усиление негативного потенциала используемых зооморфных метафор.

После 18 марта, когда станут известны результаты выборов, можно ожидать появления новой волны анекдотов, в которых развертывание исследуемой метафоры заиграет новыми красками и даст возможность сопоставить реализацию метафорических прогнозов и метафорического подведения итогов в цикле анекдотов, объединенных тематикой участия 
столь яркой и неоднозначной персоны, как Ксения Собчак, в президентской гонке.

\section{Литература}

1. Щенникова О.Н. Неформальная коммуникация в политике // Известия Алтайского государственного университета. 2008. № 4 (60). С. 207-208.

2. Чудинов А.П. Политическая лингвистика. М. : Флинта : Наука, 2012. 256 с.

3. Алексеев B.B. Политический анекдот периода перестройки как исторический источник. URL: http://pandia.ru/text/77/369/69560.php (дата обращения: 20.12.2017).

4. Будко Д.А. Политический юмор как объект исследования в политической науке (на примере политического анекдота) // Вестник Санкт-Петербургского государственного университета. Сер. 6: Политология. Международные отношения. 2015. Вып. 3. C. $70-82$.

5. Мельниченко М. А. Советский политический анекдот 1918-1953 годов как исторический источник : автореф. дис. ... канд. ист. наук. М., 2011. 19 с.

6. Фролова O.В. Событие советской истории и его отражение в политическом анекдоте // Традиционная культура. 2010. Т. 38. С. 128-134.

7. Карасик В.И. Анекдот как предмет лингвистического изучения // Жанры речи : межвуз. сб. нач. тр. Саратов, 1997. Вып. 1. С. 144-153.

8. Желтухина М.Р. Политический анекдот как жанр политического комического в массовой медиакультуре // Аксиологическая лингвистика : игровое и комическое в общении: сб. науч. тр. / под ред. В.И. Карасика. Волгоград, 2003. С. 96-112.

9. Култышева И.В. Категория комического в репрезентации образа политического врага (на примере политического анекдота) // Политическая лингвистка. 2016. № 2. C. $74-79$.

10. Шмелева Е.Я., Шмелев А.Д. Русский анекдот: Текст и речевой жанр. М. : Языки славянской культуры, 2002. $144 \mathrm{c}$.

11. Нагуш Н.В. Механизмы функционирования метафоры в анекдоте (на материале современного немецкого языка) : дис. ... канд. филол. наук. Иркутск, 2006. 169 с.

12. Лакофф Дж., Джонсон М. Метафоры, которыми мы живем. М. : УРСС Эдиториал, 2004. $256 \mathrm{c}$.

13. Баранов А.Н. Дескрипторная теория метафоры. М. : Языки славянской культуры, 2014. $632 \mathrm{c}$.

14. Кобозева И.М. Лексико-семантические заметки о метафоре в политическом дискурсе // Политическая лингвистика. 2010. № 2 (32). С. 41-46.

15. Резанова 3.И. Метафорический фрагмент русской языковой картины мира: идеи, методы, решения // Вестник Томского государственного университета. Филология. 2010. № 1 (9). C. 26-43.

16. Чудинов А.П. Россия в метафорическом зеркале: Когнитивное исследование политической метафоры (1991-2000). Екатеринбург, 2001. 238 с.

17. Колотнина E.B., Ваганова T.A. К вопросу о развертывании концептуальной метафоры в тексте (на примере текстов экономической тематики) // Современные проблемы гуманитарных наук. 2016. № 5. С. 59-62.

18. Анекдоты из России. URL: https://www.anekdot.ru/ (дата обращения: 14.10.2017-31.12.2017)

19. Шмелева Е.Я., Шмелев А.Д. Политическая жизнь в зеркале русского анекдота // Современная политическая лингвистика : тез. Междунар. науч. конф. / гл. ред. А.П. Чудинов. Екатеринбург, 2003. С. 184-186.

20. Бытотова Л.И. Отражение концепта «лошадь» в языковом сознании русских и хакасов (на материале пословиц и поговорок) // Филологические науки в России и за рубежом. Казань, 2013. С. 40-46. 
21. Кондратьева О.Н. Динамика метафорических моделей в русской лингвокультуре (XI-XX вв.) : автореф. дис. ... д-ра филол. наук. Екатеринбург, 2014. 46 с.

22. Ефремова Т.Ф. Новый словарь русского языка: Толково-словообразовательный. M. : Рус. яз., 2000. URL: https://www.efremova.info/ (дата обращения: 05.01.2018).

23. Воробьева Д. Метафоры цирка // Диалог искусств. 2014. № 2. URL: http://di.mmoma.ru/news?mid=358\&id=45 (дата обращения: 06.01.2018).

24. Елистратов В.С. Словарь русского арго. М. : Рус. сл., 2000. 694 с. URL: http:/gramota.ru/slovari/argo/ (дата обращения: 05.01.2018).

Features of Representing the Conceptual Metaphor in a Cycle of Political Jokes (On the Material of Jokes About Kseniya Sobchak's Running for President of the Russian Federation)

Vestnik Tomskogo gosudarstvennogo universiteta. Filologiya - Tomsk State University Journal of Philology. 2019. 60. 28-44. DOI: 10.17223/19986645/60/3

Olga N. Kondratyeva, Kemerovo State University (Kemerovo, Russian Federation). E-mail: Kondr25@rambler.ru / Olnik25@mail.ru

Keywords: conceptual metaphor, use of conceptual metaphor, political joke, presidential elections-2018, Kseniya Sobchak.

The reported research was funded by the Russian Foundation for Basic Research and Kemerovo Region Administration, Grant No. 18-412-420003 p_a.

The article is devoted to the description of the features of a metaphorical model representation in political jokes. The model represents an event significant for modern Russian politics - a female candidate, Kseniya Sobchak, ran for president of the Russian Federation in 2018. The material of the research was jokes from the Anekdoty iz Rossii [Jokes from Russia] website for the period from 14 October 2017 till 1 January 2018. In the cycle of jokes about Kseniya Sobchak's participation in presidential election, the metaphor of a horse became dominating. Its efficiency is determined by the following factors: (1) mass linguaculture has already fixed the comparison of Kseniya Sobchak with a horse; (2) the image of a horse is meaningful for Russian linguaculture; (3) horse-related images of a horse race, a race, a hippodrome, a tote and a circus are traditionally used for a metaphorical designation of election campaigns. In jokes about the 2018 Russian presidential election, the initial metaphor "Presidential Candidate (Sobchak) Is a Horse (a dark horse or a Trojan Horse)" developed adjacent metaphors: "Presidential Election Is a Race / Hippodrome / Circus", "President Is the Organizer of a Race / Tote", "Alternative Candidates Are Equestrians", "Voters Are a Herd". The metaphor of a horse used for characterising Sobchak appeared prior to the beginning of the 2018 presidential race. However, during the period under study, it became more frequent and more structured and acquired additional meanings. If earlier the target of metaphorical expansion was Sobchak's appearance and behaviour, during the period under study, the accent was made on her unexpected running for president, the frame-up character of her candidacy, her superficial intentions, the negative consequences of her unlike victory, i.e., authors of jokes believe she does not fit the post she is running for and the whole situation is illogical and absurd. It is also necessary to note that jokes before Sobchak's runing for president were ironic while during the period under study they became sarcastic, with the growing negative potential of the animal metaphors in them. After the announcement of the election results, a new wave of jokes can be expected, in which the metaphor under study will have new representations, which will help compare the metaphorical forecast implementation and metaphorical summarizing in a cycle of jokes on the participation in the presidential race of the bright and ambiguous person, Kseniya Sobchak. 


\section{References}

1. Shchennikova, O.N. (2008) Neformal'naya kommunikatsiya v politike [Informal communication in politics]. Izvestiya Altayskogo Gosudarstvennogo Universiteta - Izvestiya of Altai State University. 4 (60). pp. 207-208.

2. Chudinov, A.P. (2012) Politicheskaya lingvistika [Political Linguistics]. Moscow: Flinta; Nauka.

3. Alekseev, V.V. (n.d.) Politicheskiy anekdot perioda perestroyki kak istoricheskiy istochnik [Political joke of the perestroika period as a historical source]. [Online] Available from: http://pandia.ru/text/77/369/69560.php. (Accessed: 20.12.2017).

4. Budko, D.A. (2015) Political Humour as an Object of Political Science (Case of Political Jokes). Vestnik Sankt-Peterburgskogo gosudarstvennogo universiteta. Politologiya. Mezhdunarodnye otnosheniya. - Vestnik of Saint Petersburg University. Political Science. International Relations 3. pp. 70-82. (In Russian).

5. Mel'nichenko, M.A. (2011) Sovetskiy politicheskiy anekdot 1918-1953 godov kak istoricheskiy istochnik [Soviet Political Joke of 1918-1953 as a Historical Source]. Abstract of History Cand. Diss. Moscow.

6. Frolova, O.V. (2010) Sobytie sovetskoy istorii i ego otrazhenie v politicheskom anekdote [Event in the Soviet History and Its Reflection in a Political Joke]. Traditsionnaya kul'tura - Traditional Culture. 38. pp. 128-134. (In Russian).

7. Karasik, V.I. (1997) Anekdot kak predmet lingvisticheskogo izucheniya [Joke as as a Subject of Linguistic Study]. Zhanry rechi-Speech Genres. 1. pp. 144-153. (In Russian).

8. Zheltukhina, M.R. (2003) Politicheskiy anekdot kak zhanr politicheskogo komicheskogo v massovoy mediakul'ture [Political Joke as a Genre of Political Comedy in Mass Media Culture]. In: Karasik, V.I. (ed.) Aksiologicheskaya lingvistika: igrovoe $i$ komicheskoe v obshchenii [Axiological Linguistics: Playful and Comic in Communication]. Volgograd: Peremena. pp. 96-112.

9. Kultysheva, I.V. (2016) The Category of Comic in Representation of the Image of Political Opponent (on the Example of Political Anecdote). Politicheskaya lingvistka Political Linguistics. 2. pp. 74-79. (In Russian).

10. Shmeleva, E.Ya. \& Shmelev, A.D. (2002) Russkiy anekdot: Tekst i rechevoy zhanr [Russian Joke: Text and a Speech Genre]. Moscow: Yazyki russkoy kul'tury.

11. Nagush, N.V. (2006) Mekhanizmy funktsionirovaniya metafory $v$ anekdote (na materiale sovremennogo nemetskogo yazyka) [The Mechanisms of Metaphor Functioning in a Joke (Based on the Material of the Modern German Language)]. Philology Cand. Diss. Irkutsk.

12. Lakoff, G. \& Johnson, M. (2004) Metafory, kotorymi my zhivem [Metaphors We Live By]. Translated from English. Moscow: URSS Editorial.

13. Baranov, A.N. (2014) Deskriptornaya teoriya metafory [The Descriptory Theory of Metaphor]. Moscow: Yazyki russkoy kul'tury.

14. Kobozeva, I.M. (2010) Lexico-Semantic Notes on a Metaphor in Political Discourse. Politicheskaya lingvistka - Political Linguistics. 2 (32). pp. 41-46. (In Russian).

15. Rezanova, Z.I. (2010) Metaphorical segment of Russian linguistic picture of the world:ideas, methods, solutions . Vestnik Tomskogo gosudarstvennogo universiteta. Filologiya - Tomsk State University Journal of Philology. 1 (9). pp. 26-43. (In Russian).

16. Chudinov, A.P. (2001) Rossiya v metaforicheskom zerkale: Kognitivnoe issledovanie politicheskoy metafory (1991-2000) [Russia in a Metaphorical Mirror: a Cognitive Study of Political Metaphor (1991-2000)]. Yekaterinburg: Ural State Pedagogical University.

17. Kolotnina, E.V. \& Vaganova, T.A. (2016) K voprosu o razvertyvanii kontseptual'noy metafory v tekste (na primere tekstov ekonomicheskoy tematiki) [On the Question of the Conceptual Metaphor Deployment in the Text (on the Example of Texts on Economic Subjects)]. Sovremennye problemy gumanitarnykh nauk. 5. pp. 59-62. 
18. Anekdoty iz Rossii [Jokes from Russia]. [Online] Available from: https://www.anekdot.ru/. (Accessed: 14.10.2017-31.12.2017)

19. Shmeleva, E.Ya. \& Shmelev, A.D. (2003) Politicheskaya zhizn' v zerkale russkogo anekdota [Political Life in the Mirror of Russian Joke]. In: Chudinov, A.P. (ed.) Sovremennaya politicheskaya lingvistika [Modern Political Linguistics]. Abstracts of the International Conference. Yekaterinburg: Ural State Pedagogical University. pp. 184-186. (In Russian).

20. Bytotova, L.I. (2013) [Reflection of the "Horse" Concept in the Linguistic Consciousness of Russians and Khakasses (Based on Proverbs and Sayings)]. Filologicheskie nauki $v$ Rossii $i$ za rubezhom [Philological Sciences in Russia and Abroad]. Proceedings of the International Conference. St. Petersburg. November 2013. St. Petersburg: Renome. pp. 40-46. (In Russian).

21. Kondrat'eva, O.N. (2014) Dinamika metaforicheskikh modeley $v$ russkoy lingvokul'ture $(X I-X X v v$.) [Dynamics of Metaphorical Models in Russian Linguistic Culture (11th-20th Centuries)]. Abstract of Philology Dr. Diss. Yekaterinburg.

22. Efremova, T.F. (2000) Novyy slovar' russkogo yazyka: Tolkovo-slovoobrazovatel'nyy [New Dictionary of the Russian Language: Definition and Word-formation]. Moscow: Russkiy yazyk. [Online] Available from: https://www.efremova.info/. (Accessed: 05.01.2018).

23. Vorob'eva, D. (2014) Metafory tsirka [Circus Metaphors]. Dialog iskusstv - Dilogue of Arts. 2. [Online] Available from: http://di.mmoma.ru/news?mid=358\&id=45. (Accessed: 06.01.2018).

24. Elistratov, V.S. (2000) Slovar' russkogo argo [Russian Argot Dictionary]. Moscow: Russkiye slovari. [Online] Available from: http://gramota.ru/slovari/argo/. (Accessed: 05.01.2018). 